\title{
academicJournals
}

Vol. 8(45), pp. 3751-3760, 5 November, 2014

DOI: $10.5897 /$ AJ MR2014.7016

Article Number. AD87ECB48661

ISSN 1996-0808

Copyright $\odot 2014$

African Journal of Microbiology Research

Author(s) retain the copyright of this article

http://www.academic joumals.org/AJ MR

\section{Assessment of fungi in soils of sugarcane crops and their potential for production of biomass-degrading enzymes}

\author{
Tássia Chiachio Egea ${ }^{1 *}$, Andre Rodrigues ${ }^{2}$, Priscila Atique de Morais ${ }^{1}$, Roberto da Silva $^{1}$ and \\ Eleni Gomes ${ }^{1}$
}

${ }^{1}$ Laboratory of Biochemistry and Applied Microbiology, Department of Biology, IBILCE, UNESP - São Paulo State University, São José do Rio Preto, SP, Brazil.

${ }^{2}$ Laboratory of Fungal Ecology and Systematics, Department of Biochemistry and Microbiology, IB, UNESP - São Paulo State University, Rio Claro, SP, Brazil.

Received 15 July, 2014; Accepted 20 October, 2014

\begin{abstract}
Soil management practices are known to affect the biomass and enzyme activities of microbial soil communities. To assess whether burning of sugarcane prior to harvesting affects the community of soilborne fungi, we collected soil samples in two sites: burned sugarcane culture prior harvesting (BS) and non-burned sugarcane culture (NBS). A total of 75 filamentous fungal isolates were recovered from soils in both sites. Trichoderma was the most prevalent genus in both sites, followed by Fusarium, Cunninghamella and Aspergillus. The Sorensen's index (0.62) suggested a slight difference in fungi associated with both areas, with high number of fungal isolates found on BS soil. The abundance of Trichoderma isolates in NBS soil was higher than BS soil; however, the abundance of Fusarium, Aspergillus and Cunninghamella was higher in the latter type of soil. In addition, fungi isolated from BS soil showed the highest production of xylanase and laccase in comparison with fungi derived from NBS soil. Our results indicate that the different types of sugarcane harvesting apparently did not interfere with the diversity of fungal communities as revealed by culture-dependent methods. In addition, our data indicates the potential of fungi from soils of sugarcane crops to produce relevant enzymes related to biomass conversion.
\end{abstract}

Key words: Culture-dependent analysis, harvest system, agriculture residues, biotechnological potential.

\section{INTRODUCTION}

Ethanol as an alternative energy source to petroleumbased fuels has been encouraged in Brazil since the 1970 's. Due to suitable climate, available agricultural land and fertile soils, cultivation of sugarcane for ethanol production reached 600 million tons at 2014 (Union of Sugarcane Industry of São Paulo- UNICA). This dramatic increase in the sugar and ethanol sectors may entail significant changes in cultivated soils resulting from

${ }^{*}$ Corresponding author. E-mail: tassiaegea@gmail.com.

Author(s) agree that this article remain permanently open access under the terms of the Creative Commons Attribution License 4.0International License 
management practices and frequent use of pesticides (Viana and Perez, 2013).

The sustainability of soil ecosystems depends on the microorganisms which are responsible for the net fluxes of carbon soil through organic matter degradation. In general, the integrity of soil microbial communities can be used as indicator of changes in soil properties (MataixSolera et al., 2009). The abundance and activity of the soil microbiota may be directly affected by several environmental factors, thus highlighting the need for studies focused on genetic and functional diversity in such communities. Regarding the latter, different types of soil management disturbs functional microbial diversity (Yang et al., 2006; Capelle et al., 2012). The various soil management practices are also known to affect the microbial biomass and enzyme activities such as urease, phosphatase, deaminase and plant cell wall degrading enzymes like cellulase, xylanase and ligninase (Ajwa et al., 1999; Fioretto et al., 2002; Barreiro et al., 2010).

Although sugarcane burning is no longer a concern in Brazil, since all cane cutting has been mechanized (Viana and Perez, 2013), burning is still widely used in some countries such as South Africa and Nigeria (Are et al., 2009; Smithers, 2014). The practice of burning the sugarcane before harvesting facilitates manual cutting by removing leaves and insects (Thorburn et al., 2001); however, it results in modifications of the soil's physical, chemical, biological and hydrological properties (Cerri et al., 2007; Are et al., 2009).

In particular, fire may directly cause microbial mortality or indirectly induce changes in microbial community through modification of the physical/chemical properties and interactions with other soil organisms (Widden and Pakkinson, 1975; Certini, 2005). On the other hand, the mechanical sugarcane harvest causes soil compaction, resulting in a decrease in the dissolved oxygen, soil porosity and nutrient mobility (Blair, 2000; Braunack et al., 2006), ultimately reducing crop yield and fungal growth.

Information regarding the effects of periodic practices of burning on sugarcane crops has been generalized as microbial biomass determination (Graham et al., 2002; Galdos et al., 2009; Souza et al., 2012). Knowledge on the microbial communities and their activities can improve the understanding of the role played by microbes in soil communities. Here, we compared the effects of two types of sugarcane harvesting, burning and mechanical, on the functional role of the major fungal taxa found in soil. Fungi associated with oils under two types of sugarcane harvesting were isolated and the potential of these strains in the production of enzymes involved in biomass degradation was evaluated.

\section{MATERIALS AND METHODS}

Sampling

Soil samples were collected at two distinct sites from a sugarcane crop located in José Bonifácio, São Paulo State, Brazil (GPS: $21^{\circ} 03^{\prime} \mathrm{S}$; $\left.49^{\circ} 42^{\prime} \mathrm{W}\right)$. Each site was under different crop managements since 2005: (i) sugarcane was burned before harvesting (BS- dystrophic haplicgleysol soil) and (ii) green harvest (non-burned sugarcane, NBS- dystrophic red latosol soil). In each site, soil samples were collected four times across crop stages: (1) before soil preparation; (2) during soil preparation (tillage: when fertilizers and herbicides were applied); (3) mature culture and (4) after harvesting the sugarcane. In the case of stage \#2, the herbicide mixture consisted of Velpar- $\mathrm{k}^{\circledR}$ (Diuron plus Hexazinone), Ametrine $^{\circledR}$ (Triazine) and Msma ${ }^{\circledR}$ (Arsenical).

All soil samples were collected at three different points and pooled in order to obtain a composite sample. Thus, a total of four pooled samples were obtained from each area (representing the four crop stages). Approximately $1 \mathrm{~g}$ of surface soil $(0-5 \mathrm{~cm})$ was collected with a small shovel and transferred to vials containing sterilized culture medium. The samples were stored in boxes at room temperature and delivered directly to the incubator at $28 \pm$ $2^{\circ} \mathrm{C}$.

\section{Isolation and identification of soil fungi}

One gram of soil was inoculated in four types of liquid medium containing different carbon sources: glucose, wheat bran, sugarcane bagasse or filter paper as carbon sources. A variety of carbon substrates were employed due to the different responses of extracellular enzyme production by the fungi (Massadeh et al., 2010; Schneider et al., 2014). A modified version of the culture medium formulated by Kirk et al. (1978) was used (in $\mathrm{g} \mathrm{L}^{-1}$ at $\mathrm{pH}$ 5.0): 5.0 of carbon source, 1.4 of $\left(\mathrm{NH}_{4}\right)_{2} \mathrm{SO}_{4}, 2.0$ of $\mathrm{KH}_{2} \mathrm{PO}_{4}, 0.03$ of $\mathrm{CaCl}_{2}, 0.02$ of $\mathrm{MgSO}_{4} .7 \mathrm{H}_{2} \mathrm{O}, 0.4$ of peptone, 0.1 of Tween 80 and $0.5 \mathrm{~mL}$ of mineral solution (in $\mathrm{g} \mathrm{L}^{-1}: 0.22$ of $\mathrm{ZnSO}_{4} .7 \mathrm{H}_{2} \mathrm{O} ; 1.0$ of $\mathrm{H}_{3} \mathrm{BO}_{3} ; 0.5$ of $\mathrm{MnCl}_{2} .4 \mathrm{H}_{2} \mathrm{O}, 0.5$ of $\mathrm{FeSO}_{4} .7 \mathrm{H}_{2} \mathrm{O} ; 0,16$ of $\mathrm{CoCl}_{2} .5 \mathrm{H}_{2} \mathrm{O}$; 0.16 of $\mathrm{CuSO}_{4} .5 \mathrm{H}_{2} \mathrm{O}$ and 0.11 of $\left(\mathrm{NH}_{4}\right) \mathrm{Mo}_{7} \mathrm{O}_{24} .4 \mathrm{H}_{2} \mathrm{O} ; 5.0$ of EDTA). The antibiotics, ampicillin and chloramphenicol $\left(200 \mu \mathrm{g} \mathrm{L}^{-1}\right)$ were supplemented to the media. All media were incubated at $28 \pm 2^{\circ} \mathrm{C}$ for $72 \mathrm{~h}$ and a loop full of the homogenized culture was streaked on a Petri dish containing the solid version of the same medium and incubated at $28 \pm 2^{\circ} \mathrm{C}$ for 24 to $72 \mathrm{~h}$. Fungal isolates were subcultured until pure cultures were obtained. All strains were maintained on potato dextrose agar (PDA) slants and under mineral oil and were kept at room temperature.

Fungal isolates were first screened in order to group them into morphospecies. Fungal identification was carried out using morphological markers (colony macroscopic characters as well as micromorphology of asexual reproductive structures). Classical taxonomic treatments were used to carry out the identification (Domsch et al., 1980; Samson et al., 2000; Kirk et al., 2001).

\section{Enzyme production in solid-state fermentation (SSF)}

Five grams of mixtures of wheat bran and sugarcane bagasse $(1: 1$, $\mathrm{wt} / \mathrm{wt}$ ) were placed in polypropylene bags and sterilized at $120^{\circ} \mathrm{C}$ for $20 \mathrm{~min}$. This substrate was inoculated with $20 \mathrm{~mL}$ of a spore suspension, obtained from cultures previously grown for five days and was moistened with nutrient solution containing $\left(\mathrm{g} \mathrm{L}^{-1}\right) 0.5$ of $\mathrm{MgSO}_{4} .7 \mathrm{H}_{2} \mathrm{O}, 3.5$ of $(\mathrm{NH} 4)_{2} \mathrm{SO}_{4}, 3.0$ of $\mathrm{KH}_{2} \mathrm{PO}_{4}$ and 0.5 of $\mathrm{CaCl}_{2}$, $\mathrm{pH} 5,0$. The solid state fermentation was carried out at $28^{\circ} \mathrm{C}$ for 10 days. Every $48 \mathrm{~h}$, one bag was removed and the fermented material was mixed with $8 \mathrm{~mL}$ of distilled water per gram of fermented material, stirred for $30 \mathrm{~min}$, filtered, and centrifuged at $8000 \mathrm{~g}$ and $5^{\circ} \mathrm{C}$. The supernatant was used as crude enzyme solution.

\section{Enzyme activity assays}

Endo-glucanase and xylanase activities were assayed in a reaction 
mixture containing $0.1 \mathrm{~mL}$ of crude enzyme solution and $0.9 \mathrm{~mL}$ of sodium acetate buffer solution at $0.1 \mathrm{M}$, pH 5.0 in addition to carboxy methyl cellulose (CMC) or xylan (Birchwood) at $5.0 \mathrm{~g} \mathrm{~L}^{-1}$; and were incubated at $40^{\circ} \mathrm{C}$ for $10 \mathrm{~min}$. The quantification of released reducing sugar (expressed as glucose or xylose) was carried out by the 3,5-dinitrosalicylic acid (DNS) method designed by Miller (1959) based on glucose and xylose standard curves.

Laccase activity was determined via the oxidation of 2,2'-azinobis(3-ethylbenzthiazoline)-6-sulfonate (ABTS). The reaction mixture, containing $0.1 \mathrm{~mL}$ of $0.3 \mathrm{mM}$ ABTS in $100 \mathrm{mM}$ sodium acetate $(\mathrm{pH} 5.0)$ and $0.1 \mathrm{~mL}$ of crude enzyme solution, was incubated at $40^{\circ} \mathrm{C}$ for $1 \mathrm{~min}$. The oxidation was followed by the increase in absorbance at $420 \mathrm{~nm}$ in spectrophotometer (Bechman) $\left(\varepsilon=36000 \mathrm{I} \mathrm{mol}^{-1} \mathrm{~cm}^{-1}\right)$. One enzyme unit $(U)$ was defined as 1 $\mu \mathrm{mol}$ of ABTS oxidized per minute and activity was expressed in $U$ $\mathrm{L}^{-1}$ (Buswell et al., 1995).

\section{Data analysis}

Composition of filamentous fungi assemblages from both areas was measured according to the Sorensen index, $S=2\left(S_{12}\right) /\left(S_{1}+S_{2}\right)$; where $S_{1}$ is the number of genera found in area BS; $S_{2}$ is the number of genera found in area NBS and $S_{12}$ is the number of genera common between the two areas.

Data regarding the enzymatic activity were $\log (x+1)$ transformed in order to approach a normal distribution and homogeneity of variances. The Student- $t$ test was used to determine significant differences in enzymatic activity (xylanase, CMCase and laccase) from each genus with a $5 \%$ significance level. The analysis was carried out in Statistica v. 7.

\section{RESULTS}

\section{Filamentous fungi isolated from burned and non- burned sugarcane soils}

To evaluate the possible effects of burning the sugarcane on the major fungal components of the soil mycota, we surveyed the fast-growing and dominant fungal taxa in two areas that differed in sugarcane harvesting treatments. A total of 75 filamentous fungal isolates were recovered from BS and NBS soils (Table 1). The Sorensen index of shared taxa resulted in the value 0.62 , which indicates a slight difference in fungal composition between soil treatments. Overall, Trichoderma was the most prevalent genus in both types of soils followed by Fusarium and Cunninghamella (Table 2). The number of Trichoderma isolates was higher in NBS soil and Aspergillus sp. was isolated in a higher number in BS soil (Student-t; $P=0.25$ ). The observed differences in the number of isolates belonging to Fusarium and Cunninghamella genera were not significantly different between soil types ( $\mathrm{t}$ test; $\mathrm{P}=0.006$ ).

Although the experiment was performed in one sugarcane cultivation cycle, after four consecutive samplings, we recovered more fungal isolates during soil preparation (stage \#2, tillage) in comparison with the other stages. The soil-borne fungi Trichoderma and Fusarium were found in all stages (Table 3 ). The intensity of rainfall and soil moisture in the sampling sites, although the great observed variation, did not affect the total number of fungal isolates. The temperature was fairly uniform in the days of sampling (Table 3).

\section{Enzyme production by filamentous fungi}

To investigate whether distinct soil conditions have impact on the functional role of fungi, the enzymatic production (cellulose, xylanase and laccase) was assessed. Overall, the observed values in the total enzyme activity by the isolated fungi from BS and NBS soils were not significantly different ( $t$ test; $P=0.002$ ); although we found a higher production of laccases and xylanases by fungi recovered from BS soils (Table 4). Interesting to note, xylanase and CMCase production were higher for fungi from the genus Aspergillus and laccase production was higher for Verticillium sp. followed by fungi from genus Fusarium (Figure 1).

\section{DISCUSSION}

Understanding how management practices influence the diversity and functional roles of soil microbial communities is paramount to develop a comprehensive view of microbes interacting with plants that promote host productivity (Fioretto et al., 2002; Barreiro et al., 2010). Our survey revealed that all fungal genera recovered from soils of sugarcane crops were also found in samples from other types of soils as described by Bordjiba et al. (2001), Silva et al. (2009) and Kutorga et al. (2012). This reveals that soils under sugarcane crops harbor a fungal community composed of ubiquitous soil-borne fungi.

Our data suggest that the practice of burning the sugarcane prior harvesting did not significantly affect the composition of the most abundant taxa of soil-borne fungi, in comparison with the site where the sugarcane was harvested green (no burning procedures were applied). Several studies reported modifications on the chemical and physical properties of soil as a result of burning such as, nutrient lack due to loss of soil organic matter and the reduction of the soil moisture (Graham et al., 2002). Thus, it was expected that soil under green harvested sugarcane would present a higher richness of fungal genera, which was not observed in the present study.

The practice of burning the sugarcane may change the microbial communities but, due to its resilience, the communities can recover in short time span (BarcenasMoreno and Baath, 2009). Fontúrbel et al. (2012) studying the effects of fire on soil microbiota showed that the biomass and activity of microorganisms in these soils were reduced by fire, however, the microbial diversity has been increased in relative proportion. In our study, we did not observe high differences in biomass composition between BS and NBS soils, but we observed that both types of soils had fungal genera that must have resisted environmental stress. One example is the genus 
Table 1. Fungal strains isolated from sugarcane soils across crop stages, in different carbon source and types of harvesting.

\begin{tabular}{|c|c|c|c|c|}
\hline Sampling & Carbon source & Type of harvesting $^{1}$ & Strain & Code \\
\hline \multirow{15}{*}{1} & \multirow{5}{*}{ Glucose } & \multirow{4}{*}{ BS } & Cunninghamella sp.1 & G01 \\
\hline & & & Fusarium sp.4 & G02 \\
\hline & & & Trichoderma sp.1 & G03 \\
\hline & & & Trichoderma virens & G04 \\
\hline & & NBS & Trichoderma sp.1 & G06 \\
\hline & \multirow{3}{*}{ Wheat bran } & BS & Fusarium sp.1 & F01 \\
\hline & & \multirow{2}{*}{ NBS } & Trichoderma sp.1 & F02 \\
\hline & & & Trichoderma harzianum species complex & F03 \\
\hline & \multirow{4}{*}{ Sugarcane bagasse } & \multirow{2}{*}{ BS } & Trichoderma sp.1 & B01 \\
\hline & & & Fusarium sp.1 & B02 \\
\hline & & \multirow{2}{*}{ NBS } & Trichoderma sp.1 & B03 \\
\hline & & & Trichoderma sp.1 & B04 \\
\hline & \multirow{3}{*}{ Filter paper } & BS & Trichoderma sp.1 & P01 \\
\hline & & \multirow{2}{*}{ NBS } & Fusarium sp.1 & P02 \\
\hline & & & Mucor hiemalis & P03 \\
\hline \multirow{25}{*}{2} & \multirow{6}{*}{ Glucose } & \multirow{4}{*}{ BS } & Aspergillus brasiliensis & G08 \\
\hline & & & Cunninghamella elegans & $\mathrm{G} 10$ \\
\hline & & & Trichoderma sp.2 & $\mathrm{G} 13$ \\
\hline & & & Cunninghamella sp.1 & G14 \\
\hline & & \multirow[t]{2}{*}{ NBS } & Trichoderma harzianum species complex & G15 \\
\hline & & & Trichoderma sp.2 & $\mathrm{G} 17$ \\
\hline & \multirow{9}{*}{ Wheat bran } & \multirow{6}{*}{ BS } & Verticillium sp. & F04 \\
\hline & & & Trichoderma sp.1 & F06 \\
\hline & & & Paecilomyces sp. & F07 \\
\hline & & & Penicillium sp. & F08 \\
\hline & & & Fusarium sp.6 & F10 \\
\hline & & & Aspergillus sect flavus & F12 \\
\hline & & \multirow{3}{*}{ NBS } & Fusarium sp.5 & F13 \\
\hline & & & Cunninghamella sp.2 & F16 \\
\hline & & & Aspergillus sect fumigati & F18 \\
\hline & \multirow{5}{*}{ Sugarcane bagasse } & \multirow{3}{*}{ BS } & Trichoderma sp.1 & B05 \\
\hline & & & Cunninghamella elegans & B06 \\
\hline & & & Aspergillus sect flavus & B07 \\
\hline & & \multirow{2}{*}{ NBS } & Trichoderma sp.1 & B13 \\
\hline & & & Cunninghamella sp.2 & B16 \\
\hline & \multirow{5}{*}{ Filter paper } & \multirow{3}{*}{ BS } & Trichoderma sp.1 & P05 \\
\hline & & & Paecilomyces sp. & P07 \\
\hline & & & Cunninghamella sp.1 & P08 \\
\hline & & & Trichoderma sp.1 & P14 \\
\hline & & NBS & Absídia sp. & $\mathrm{P} 18$ \\
\hline & & RS & Trichoderma sp.1 & G19 \\
\hline & Clusers & BS & $\mathrm{FNI}^{1}$ & G20 \\
\hline & Glucose & & Trichoderma sp.1 & $\mathrm{G} 21$ \\
\hline 3 & & NBS & Trichoderma sp. 3 & $\mathrm{G} 22$ \\
\hline 3 & & & Cunninghamella sp.1 & F19 \\
\hline & & BS & Trichoderma sp. 1 & $\mathrm{~F} 20$ \\
\hline & Wheat bran & NRS & Trichoderma asperelloides & F22 \\
\hline & & NBS & Trichoderma sp.1 & F24 \\
\hline
\end{tabular}


Table 1. Contd.

\begin{tabular}{|c|c|c|c|c|}
\hline & \multirow{6}{*}{ Sugarcane bagasse } & \multirow{4}{*}{ BS } & Cunninghamella sp.1 & B18 \\
\hline & & & Fusarium sp.1 & B19 \\
\hline & & & Aspergillus sect flavus & B20 \\
\hline & & & Aspergillus sect nigri & B21 \\
\hline & & \multirow{2}{*}{ NBS } & Mucor hiemalis & B22 \\
\hline & & & Trichoderma sp.1 & B23 \\
\hline & \multirow{4}{*}{ Filter paper } & \multirow{2}{*}{ BS } & Trichoderma sp.1 & $\mathrm{P} 19$ \\
\hline & & & Trichoderma sp.1 & $\mathrm{P} 20$ \\
\hline & & \multirow{2}{*}{ NBS } & Cunninghamella sp.1 & $\mathrm{P} 21$ \\
\hline & & & Aspergillus sect flavus & $\mathrm{P} 22$ \\
\hline \multirow{17}{*}{4} & \multirow{6}{*}{ Glucose } & \multirow{4}{*}{ BS } & Mucor hiemalis & $\mathrm{G} 23$ \\
\hline & & & Fusarium sp.1 & G24 \\
\hline & & & Aspergillus sect flavus & G25 \\
\hline & & & Fusarium sp.1 & G26 \\
\hline & & \multirow[t]{2}{*}{ NBS } & Mucor hiemalis & $\mathrm{G} 27$ \\
\hline & & & Trichoderma sp.1 & G28 \\
\hline & \multirow{4}{*}{ Wheat bran } & \multirow{2}{*}{ BS } & Fusarium sp.3 & F25 \\
\hline & & & Trichoderma sp.1 & F26 \\
\hline & & \multirow{2}{*}{ NBS } & Absídia cylindrospora & $\mathrm{F} 27$ \\
\hline & & & Trichoderma virens & F28 \\
\hline & \multirow{4}{*}{ Sugarcane bagasse } & \multirow{3}{*}{ BS } & Aspergillus sect flavus & B24 \\
\hline & & & Mucor hiemalis & B25 \\
\hline & & & Trichoderma sp.1 & B27 \\
\hline & & NBS & Fusarium sp.2 & B26 \\
\hline & \multirow{3}{*}{ Filter paper } & BS & Mucor hiemalis & P23 \\
\hline & & \multirow{2}{*}{ NBS } & Fusarium verticillioides & P24 \\
\hline & & & $\mathrm{FNI}^{1}$ & P25 \\
\hline
\end{tabular}

Crop stages: (1) before soil preparation; (2) during soil preparation (tillage); (3) mature culture and (4) after harvesting the sugarcane. ${ }^{1}$ Type of harvesting - BS: soil where sugarcane was burned before harvesting; NBS: soil where green harvesting was applied (non-burned sugarcane). ${ }^{2} \mathrm{FNI}$ : not identified.

Table 2. Prevalence of fungi in soils of sugarcane crops under different harvesting systems. Figures indicate the number of fungal isolates obtained on burned (BS) and nonburned (NBS) soils.

\begin{tabular}{lcc}
\hline \multirow{2}{*}{ Fungi } & \multicolumn{2}{c}{ Soil type } \\
\cline { 2 - 3 } & BS $^{1}$ & NBS $^{1}$ \\
\hline Absidia sp. & - & 2 \\
Aspergillus sp. & 7 & 2 \\
Cunninghamella sp. & 6 & 4 \\
Fusarium sp. & 7 & 5 \\
Mucor hiemalis & 3 & 3 \\
Paecilomyces sp. & 2 & - \\
Penicillium $\mathrm{sp}$. & 1 & - \\
Trichoderma sp. & 14 & 16 \\
Verticillium $\mathrm{sp}$. & 1 & - \\
FNI $^{2}$ & 1 & 1 \\
Total & 42 & 33 \\
\hline
\end{tabular}

${ }^{1} \mathrm{BS}$ : Soil where sugarcane was burned before harvesting; NBS: soil where green harvesting was applied (non-burned sugarcane). ${ }^{2} \mathrm{FNI}$ : not identified.
Trichoderma found as the predominant genus in both soils. Using different isolation methods or high-throughput approaches such as next generation sequencing (454 pyrosequencing) will likely reveal the presence of rare species in these environments.

Although burning sugarcane apparently does not influence soil fungal community composition, the tillage practices modifies the mycota by altering the soil physical-chemical properties (Wanga et al., 2010). This step on culture management corresponds to the soil preparation where $\mathrm{pH}$ is corrected; fertilizers are added as well as herbicides. Our results show a higher number of fungi isolated from samples of soil in the preparation phase (stage \#2), suggesting this management as an important step to restore fungal population in soil. However, this work was limited to only one crop cycle.

The greatest potential for production of xylanase and laccase presented by fungi isolated from BS samples may be related to modifications on the chemical and physical properties of the soil as a result of burning the sugarcane (Graham et al., 2002). The production of xylanase and CMCase were higher for Aspergillus 
Table 3. Physical-chemical properties and filamentous fungi found in soils under different stages of sugarcane management. Figures correspond to the number of fungal isolates obtained in both areas (BS+NBS).

\begin{tabular}{lcccc}
\hline \multirow{2}{*}{ Fungi } & \multicolumn{4}{c}{ Crop cycle $^{1}$} \\
\cline { 2 - 5 } & $\mathbf{1}$ & $\mathbf{2}$ & $\mathbf{3}$ & $\mathbf{4}$ \\
\hline Absidia sp. & - & 1 & - & 1 \\
Aspergillus sp. & - & 4 & 3 & 2 \\
Cunninghamella sp. & 1 & 6 & 3 & - \\
Fusarium sp. & 4 & 2 & 1 & 5 \\
Mucor hiemalis & 1 & - & 1 & 4 \\
Paecilomyces sp. & - & 2 & - & - \\
Penicillium $\mathrm{sp}$. & - & 1 & - & - \\
Trichoderma sp. & 9 & 8 & 9 & 4 \\
Verticillium $\mathrm{sp}$. & - & 1 & - & - \\
FNI & - & - & 1 & 1 \\
Total & 15 & 25 & 18 & 17 \\
Precipitation $(\mathrm{mm})$ & 12.9 & 107.4 & 42.0 & 162.2 \\
Humidity $(\%)$ & 52.1 & 66.1 & 67.8 & 73.1 \\
Temperature $\left({ }^{\circ} \mathrm{C}\right)$ & 29.5 & 31.4 & 29.4 & 29.2 \\
\hline
\end{tabular}

${ }^{1}$ Soil sampling was carried out: (1) period after harvest and before soil preparation; (2) during soil preparation (see text for details); (3) mature culture and (4) just after harvest of sugar cane. ${ }^{2} \mathrm{FNI}$ : not identified.

Table 4. Production of xylanase, CMCase and laccase after 10 days of solid cultivation by the filamentous fungi isolated from sugarcane soil.

\begin{tabular}{lcccc}
\hline Fungi & Strain & $\begin{array}{c}\text { Xylanase } \\
\left(\mathbf{U . m L}^{-1}\right)\end{array}$ & $\begin{array}{c}\text { CMCase } \\
\left(\text { U.mL }^{-1}\right)\end{array}$ & $\begin{array}{c}\text { Laccase } \\
\left(\text { U.mL }^{-1}\right)\end{array}$ \\
\hline Abisidia sp. & $\mathrm{P} 18$ & 5.1 & 1.5 & 0.03 \\
Absidia cylindrospora & $\mathrm{F} 27$ & 1.4 & 0.3 & - \\
Aspergillus sect flavus & $\mathrm{P} 22$ & 64.0 & 3.3 & 0.04 \\
Aspergillus sect nigri & $\mathrm{B} 21$ & 63.7 & 5.2 & 0.01 \\
Aspergillus sect flavus & $\mathrm{B} 24$ & 60.2 & 2.6 & - \\
Aspergillus sect fumigati & $\mathrm{F} 18$ & 60.0 & 3.8 & 0.01 \\
Aspergillus sect flavus & $\mathrm{G} 25$ & 54.9 & 2.9 & - \\
Aspergillus sect flavus & $\mathrm{B} 07$ & 52.4 & 2.6 & 0.01 \\
Aspergillus sect flavus & $\mathrm{B} 20$ & 47.9 & 2.3 & - \\
Aspergillus sect flavus & $\mathrm{F} 12$ & 47.6 & 3.4 & - \\
Aspergillus brasiliensis & $\mathrm{G} 08$ & 43.7 & 4.2 & 0.01 \\
Cunninghamella elegans & $\mathrm{G} 10$ & 8.7 & 0.9 & - \\
Cunninghamella sp.1 & $\mathrm{G} 01$ & 3.3 & 0.8 & 0.06 \\
Cunninghamella sp.1 & $\mathrm{P} 21$ & 2.9 & 0.4 & 0.01 \\
Cunninghamella sp.2 & $\mathrm{B} 16$ & 2.8 & 0.8 & 0.09 \\
Cunninghamella sp.1 & $\mathrm{F} 19$ & 2.6 & 0.4 & 0.01 \\
Cunninghamella elegans & $\mathrm{B} 06$ & 2.5 & 1.2 & 0.13 \\
Cunninghamella sp.1 & $\mathrm{P} 08$ & 1.5 & 0.8 & 0.12 \\
Cunninghamella sp.1 & $\mathrm{G} 14$ & 0.7 & 0.4 & 0.01 \\
Cunninghamella sp.1 & $\mathrm{B} 18$ & 0.6 & 0.3 & - \\
Cunninghamella sp.2 & $\mathrm{F} 16$ & 0.6 & 0.4 & 0.10 \\
FN1 & $\mathrm{P} 25$ & 1.6 & 0.5 & 0.01 \\
FNI ${ }^{1}$ & $\mathrm{G} 20$ & 5.8 & 1.4 & 0.01 \\
Fusarium sp.1 & $\mathrm{B} 02$ & 14.7 & 1.3 & 0.27 \\
\hline
\end{tabular}


Table 4. Contd.

\begin{tabular}{|c|c|c|c|c|}
\hline Fusarium verticillioides & P24 & 3.6 & 0.8 & 0.03 \\
\hline Fusarium sp.1 & P02 & 8.5 & 0.6 & 0.01 \\
\hline Fusarium sp.2 & B26 & 7.9 & 1.7 & 0.15 \\
\hline Fusarium sp.1 & G24 & 6.9 & 5.5 & 0.24 \\
\hline Fusarium sp.4 & G02 & 5.0 & 0.8 & 0.07 \\
\hline Fusarium sp.1 & F01 & 3.8 & 2.2 & 0.10 \\
\hline Fusarium sp.5 & F13 & 3.5 & 2.2 & 0.17 \\
\hline Fusarium sp.6 & F10 & 3.2 & 0.6 & 0.03 \\
\hline Fusarium sp.3 & F25 & 2.7 & 1.5 & 0.02 \\
\hline Fusarium sp.1 & B19 & 2.1 & 1.8 & 0.01 \\
\hline Fusarium sp.1 & G26 & 2.0 & 1.8 & 0.07 \\
\hline Mucor hiemalis & B25 & 16.8 & 1.8 & 0.01 \\
\hline Mucor hiemalis & $\mathrm{G} 27$ & 12.2 & 1.5 & - \\
\hline Mucor hiemalis & P03 & 6.2 & 1.9 & 0.02 \\
\hline Mucor hiemalis & P23 & 2.4 & 0.9 & 0.03 \\
\hline Mucor hiemalis & $\mathrm{G} 23$ & 2.2 & 0.5 & 0.24 \\
\hline Mucor hiemalis & B22 & 0.5 & 0.4 & - \\
\hline Paecilomyces sp. & F07 & 1.9 & 0.8 & 0.04 \\
\hline Paecilomyces sp. & $\mathrm{P} 07$ & 1.0 & 0.6 & 0.12 \\
\hline Penicillium sp. & F08 & 13.7 & 1.9 & 0.02 \\
\hline Trichoderma sp.1 & P01 & 18.3 & 1.8 & 0.01 \\
\hline Trichoderma virens & F28 & 16.8 & 4.3 & - \\
\hline Trichoderma sp.1 & P20 & 15.0 & 3.6 & 0.01 \\
\hline Trichoderma sp.1 & B03 & 13.7 & 1.4 & 0.01 \\
\hline Trichoderma virens & G04 & 13.5 & 2.9 & 0.02 \\
\hline Trichoderma sp.1 & $\mathrm{G} 28$ & 13.4 & 3.1 & 0.01 \\
\hline Trichoderma sp.1 & P05 & 12.7 & 2.2 & 0.01 \\
\hline $\begin{array}{l}\text { Trichoderma harzianum } \\
\text { species complex }\end{array}$ & F03 & 12.4 & 1.5 & 0.02 \\
\hline Trichoderma sp.2 & G17 & 12.3 & 2.2 & 0.01 \\
\hline Trichoderma sp.1 & G19 & 11.6 & 3.9 & 0.05 \\
\hline Trichoderma sp.2 & G13 & 9.5 & 3.2 & 0.01 \\
\hline Trichoderma sp.1 & P19 & 9.4 & 4.4 & 0.01 \\
\hline Trichoderma sp.1 & F02 & 9.0 & 2.5 & - \\
\hline Trichoderma sp.1 & P14 & 8.9 & 3.2 & 0.03 \\
\hline Trichoderma sp.1 & G06 & 8.8 & 2.1 & 0.03 \\
\hline $\begin{array}{l}\text { Trichoderma harzianum } \\
\text { species complex }\end{array}$ & G15 & 8.0 & 4.7 & 0.05 \\
\hline Trichoderma sp.1 & G03 & 7.4 & 3.4 & 0.02 \\
\hline Trichoderma sp.1 & F26 & 6.9 & 2.2 & - \\
\hline Trichoderma sp.1 & B23 & 6.0 & 1.6 & 0.02 \\
\hline Trichoderma sp.1 & B27 & 5.3 & 2.0 & - \\
\hline Trichoderma sp.1 & B05 & 4.9 & 2.1 & 0.01 \\
\hline Trichoderma sp.1 & F24 & 4.6 & 2.4 & 0.06 \\
\hline Trichoderma sp.1 & B13 & 4.6 & 1.2 & 0.01 \\
\hline Trichoderma sp.1 & B04 & 4.5 & 1.3 & 0.01 \\
\hline Trichoderma sp.1 & G21 & 4.4 & 2.1 & 0.01 \\
\hline Trichoderma sp.1 & F06 & 4.2 & 1.5 & - \\
\hline Trichoderma sp.3 & G22 & 4.0 & 1.0 & 0.01 \\
\hline Trichoderma sp.1 & B01 & 3.6 & 0.8 & 0.13 \\
\hline $\begin{array}{l}\text { Trichoderma } \\
\text { asperelloides }\end{array}$ & $\mathrm{F} 22$ & 3.5 & 2.1 & 0.02 \\
\hline
\end{tabular}


Table 4. Contd

\begin{tabular}{lllll}
\hline Trichoderma sp.1 & F20 & 3.5 & 1.9 & 0.03 \\
Verticillium sp. & F04 & 1.3 & 0.3 & 0.50 \\
\hline
\end{tabular}

${ }^{1} \mathrm{FNI}$ : not identified.

A

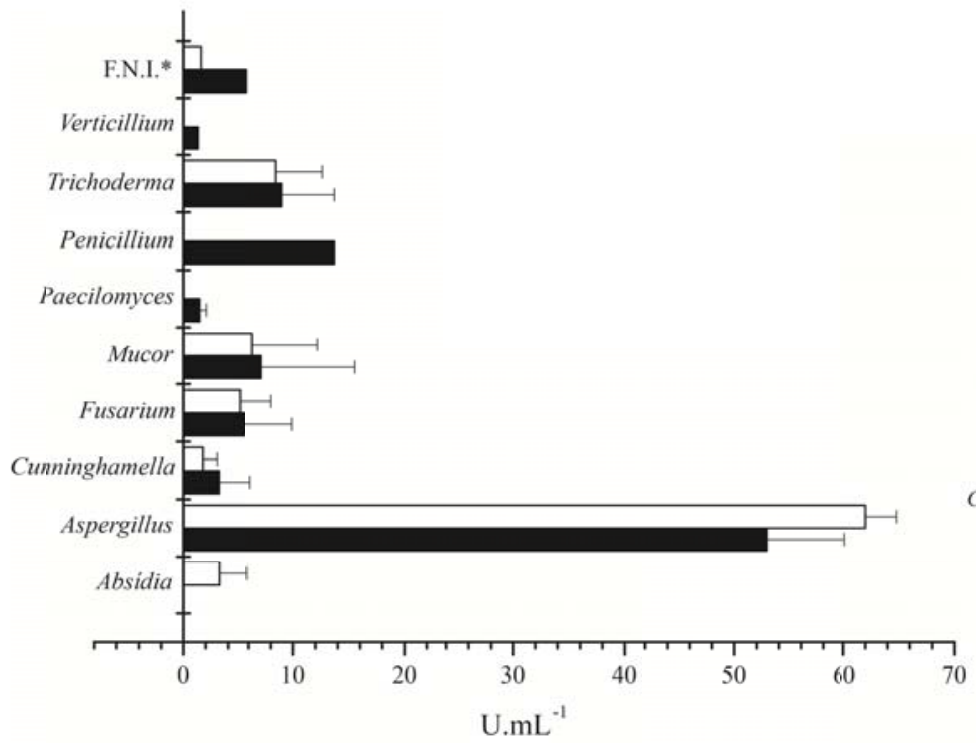

C

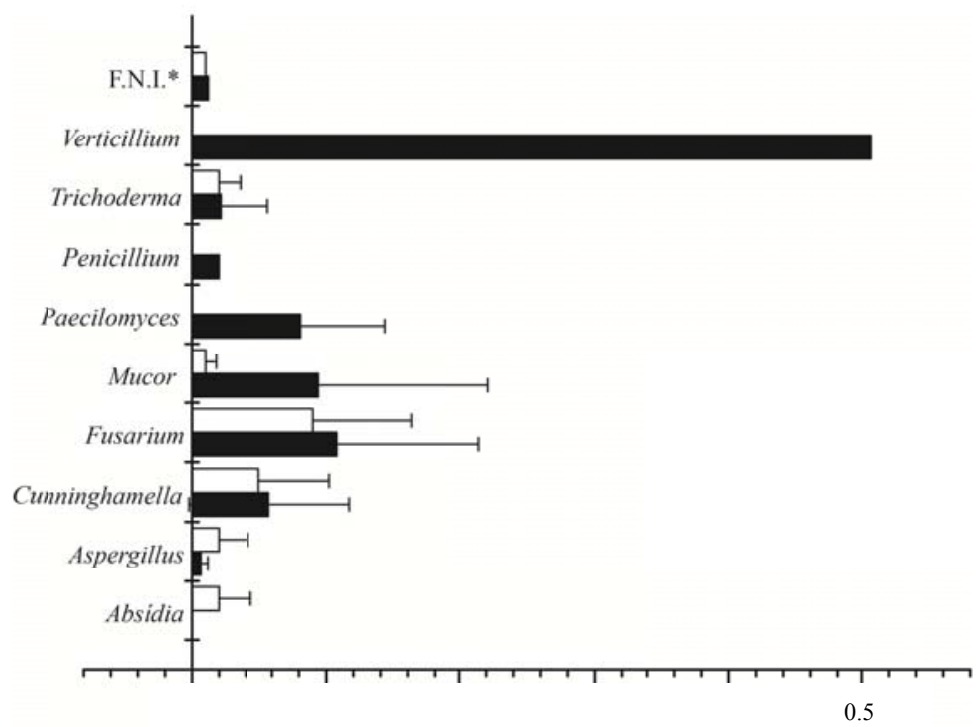

U. $\mathrm{mL}^{-1}$
B

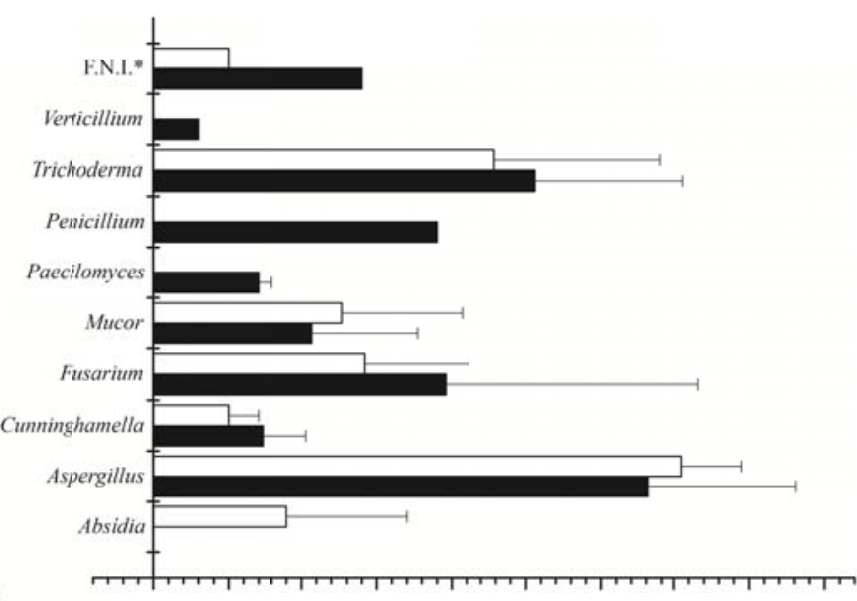

Figure 1. Enzyme activities (mean and standard deviations) of filamentous fungi isolated from burned (dark bars) and non-burned (open bar) sugarcane soils. A. Xylanase activity; B. CMCase activity and C. Laccase activity. * FNI: fungi not identified.

isolates, followed by fungi of the genus Trichoderma, Fusarium and Mucor. For laccase, the largest amount was produced by Verticillium sp., followed by fungi of the genera Fusarium and Mucor. This result shows the 
important role of several fungi in the degradation of lignocellulosic biomass in the soil environment. However there was wide variation in the production of these enzymes within the same genus, which can be explained by the difference in the type of soil, period of sampling and carbon source used to isolate the fungi.

This result raises an interesting hypothesis regarding the physiological effects of burning on soil fungal communities. It is likely that burning acts as a selective pressure on the soil fungal communities and that heat resistance fungi with high enzymatic profile may help the fungal community recover during the first stages after burning.

\section{Conclusions}

In conclusion, the culture-dependent methods applied in the present study showed the major fungal taxa in sugarcane soils under different stages. Our data indicates that burning the sugarcane may not affect the composition of the major fungal taxa, but the tillage practices could interfere in the soil fungal community and its functional role. Future studies using high-throughput sequencing technologies should be carried out in order to investigate in depth the modifications of burning and sugarcane managements in soil fungal communities.

\section{Conflict of Interest}

The author(s) have not declared any conflict of interests.

\section{ACKNOWLEDGEMENTS}

We thank "Fundação de Amparo à Pesquisa do Estado de São Paulo (FAPESP)" and "Conselho Nacional de Pesquisa e Desenvolvimento Tecnológico (CNPq)" for financial support and for providing a scholarship to the first author. We are also grateful to Usina Açucareira Virgulino de Oliveira S/A for permission to collect soil samples.

\section{REFERENCES}

Ajwa HA, Dell CJ, Rice CW (1999). Changes in enzyme activities and microbial biomass of tall grass prairie soil as related to burning and nitrogen fertilization. Soil Biol. Biochem. 31:769-777.

Are KS, Oluwatosin GA, Adeyolanu OD, Oke AO (2009). Slash and burn effect on soil quality of an Alfisol: soil physical properties. Soil Tillage Res. 103:4-10.

Barcenas-Moreno G, Bååth E (2009). Bacterial and fungal growth in soil heated at different temperatures to simulate a range of fire intensities. Soil Biol. Biochem. 41:2517-2526.

Barreiro A, Martín T, Carballas T, Díaz-Raviña M (2010). Response of soil microbial communities to fire and fire-fighting chemicals. Sci. Total Environ. 408:6172-6178.

Blair N (2000). Impact of cultivation and sugar-cane green trash management on carbon fractions and aggregate stability for a Chromic Luvisol in Queensland, Australia. Soil Tillage Res. 55:183-191.
Bordjiba O, Steiman R, Kadri M, Semadi A, Guiraud P (2001). Removal of herbicides from liquid media by fungi isolated from a contaminated soil. J. Environ. Qual. 30:418-426.

Braunack MV, Arvidsson J, Ha ${ }^{\circ}$ kansson I (2006). Effect of harvest traffic position on soil conditions and sugarcane (Saccharumofficinarum) response to environmental conditions in Queensland, Australia. Soil Tillage Res. 89:103-121.

Buswell JA, Cai Y, Chang S (1995). Effect of nutrient nitrogen and manganese on manganese peroxidase and laccase production by Lentinula (Lentinus) edodes. FEMS Microbiol. Lett. 128: 81-88.

Capelle C, Schrader S, Brunotte J (2012). Tillage-induced changes in the functional diversity of soil biota - A review with a focus on German data. Eur. J. Soil Biol. 50:165-181.

Cerri CEP, Sparovek G, Bernoux M, Easterling WE, Melillo JM, Cerri CC (2007). Tropical agriculture and global warming: impacts and mitigation options. Scientia Agricola. 64:83-99.

Certini G (2005). Effects of fire on properties of forest soils: a review. Oecologia, 143:1-10.

Domsch KH, Gams W, Anderson TH (1980).Compendium of soil fungi. London: Academic Press. v.1.

Fioretto A, Papa S, Aniello M, Merola R, Pellegrino A (2002). Microbial activities in burned and unburned soils in a low shrub and ecosystem. In: Trabaud, L., Prodon, R. (Eds.), Fire and Biological Processes. 151-162.

Fontúrbel MT, Barreiro A, Vega JA, Martín A, Jiménez E, Carballas T, Fernández C, Díaz-Raviña M (2012). Effects of an experimental fire and post-fire stabilization treatments on soil microbial communities. Geoderma, 191:51-60.

Galdos MV, Cerri CC, Cerri CEP (2009). Soil carbon stocks under burned and unburned sugarcane in Brazil. Geoderma 153:347-352.

Graham MH, Haynes RJ, Meyer JH (2002). Changes in soil chemistry and aggregate stability induced by fertilizer applications, burning and trash retention on a long-term sugarcane experiment in South African. Eur. J. Soil Sci. 53:589-598.

Kirk PM, Canno PF, Daird JC, Stalpers JA (2001). Ainsworth Bisby's Dictionary of the Fungi. CAB International, Wallingford. $9^{a}$ ed.

Kirk TK, Schultz E, Connors WJ, Lorenz LF, Zeiku JG (1978). Influence of culture parameters on lignin metabolism by Phanerochaete chrysosporium, Arch. Microbiol. 117:277-285.

Kutorga E, Adamonytė G, Iršènaitė R, Juzėnas S, Kasparavičius J, Markovskaja S, Motiejūnaitè J, Treigienè A (2012). Wildfire and postfire management effects on early fungal succession in Pinus mugo. Geoderma 191:70-79.

Massadeh MI, Fraij A, Fandi K (2010). Effect of Carbon Sources on The Extracellular Lignocellulolytic Enzymetic System of Pleurotus SajorCaju. Jordan J. Biol. Sci. 3(2):51-54.

Mataix-Solera J, Guerrero C, García-Orenes F, Bárcenas GM, Torre MP (2009). Forest Fire Effects on Soil Microbiology. In: Cerdà, A., Robichaud, P. R. (Eds.), Fire Effects on Soils and Restoration Strategies. Land Reconstruction and Management Series, 5. Science Publishers, Enfield, Jersey, Plymouth. pp. 133-175.

Miller GL (1959). Use of Dinitrosalicylic Acid Reagent for Determination of Reducing Sugar. Anal. Chem. 31:426-428.

Samson RA, Hoekstra ES, Frisvad JC (2000). Introduction to foodairborne fungi $\left(6^{\text {th }}\right.$ edn).Baarn: Centraal bureauvoor Schimmel cultures.

Schneider, WDH, dos Reis L, Camassola M, Dillon AJP (2014). Morphogenesis and Production of Enzymes by Penicilliumechinulatum in Response to Different Carbon Sources. BioMed Res. Int. vol. 2014, Article ID 254863, 10 pages.

Silva IS, Grossman M, Durrant LR (2009). Degradation of polycyclic aromatic hydrocarbons (2-7 rings) under microaerobic and very-lowoxygen conditions by soil fungi. Int. Biodeterior. Biodegradation 63:224-229.

Smithers J (2014). Review of sugarcane trash recovery systems for energy cogeneration in South Africa. Renew. Sustain. Energy Rev. 32:915-925.

Souza RA, Telles TS, Machado W, Hungria M, Tavares-Filho J, Guimaraes MF (2012). Effects of sugarcane harvesting with burning on the chemical and microbiological properties of the soil. Agric. Ecosyst. Environ. 155:1-6.

Thorburn PJ, Probert ME, Robertson FA (2001). Modelling decomposition 
of sugar cane surface residues with APSIM-Residue. Field Crops Res. 70: 223-232.

Viana KRO, Perez R (2013). Survey of sugarcane industry in Minas Gerais, Brazil: Focus on sustainability. Biomass Bioenergy 58: 149157.

Wanga Y, Xu J, Shen J, Luo Y, Scheu S, Ke X (2010). Tillage, residue burning and crop rotation alter soil fungal community and waterstable aggregation in arable fields. Soil Tillage Res. 107:71-79.
Widden P, Parkinson D (1975). The effects of a forest fire on soil microfungi. Soil Biol. Biochem. 7:125-138.

Yang Z, Liu S, Zheng D, Feng S (2006). Effects of cadium, zinc and lead on soil enzyme activities. J. Environ. Sci. 18:1135-1141. 